\title{
Effectiveness of some insecticides on spotted pod borer, Maruca vitrata geyer (Lepidoptera: Pyralidae) in greengram
}

\author{
Ram Kishor Meena*, Ravindra Kumar Meena ${ }^{1}$, Uadal Singh and Manohari Lal Meena \\ Department of Entomology, College of Agriculture (S.K.N.A.U.), Lalsot, Dausa (Rajasthan) India \\ (Email: rkmeena.ento@sknau.ac.in)
}

\begin{abstract}
The effect of commercially available insecticides formulations, emmamection benzoate 0.5 per cent SG $(0.5 \mathrm{~g} /$ litre of water), quinalphos per cent $25 \mathrm{EC}(2.0 \mathrm{ml} /$ lit.), novaluron 10 per cent EC $(1.0 \mathrm{ml} / \mathrm{lit}$.), Neem oil 2 per cent ( $20 \mathrm{ml} / \mathrm{lit}$.), karanj oil 2 per cent (20 ml/lit.) against the spotted pod borer, Maruca vitrata in greengram were evaluated. The most effective insecticide were emmamection benzoate > quinalphos > novaluron the maximum population reduction over control was found after 7 days of application of second spray at 15 days of interval viz., 72.66 and 68.20 per cent due to emmamection benzoate, quinalphos, respectively during 2015. A similar trend was found in 2016 and 2017. Thus, emmamection benzoate was found most effective against the spotted pod borer, Maruca vitrata Geyer (Lepidoptera: Pyralidae).
\end{abstract}

Key Words : Greengram, Emmamection Benzoate, Novaluron, Maruca vitrata

View Point Article : Meena, Ram Kishor, Meena, Ravindra Kumar, Singh, Uadal and Meena, Manohari Lal (2020). Effectiveness of some insecticides on spotted pod borer, Maruca vitrata geyer (Lepidoptera: Pyralidae) in greengram. Internat. J. agric. Sci., 16 (1) : $95-100$, DOI:10.15740/HAS/IJAS/16.1/95-100. Copyright@2020: Hind Agri-Horticultural Society.

Article History : Received : 21.10.2019; Revised : 19.11.2019; Accepted : 23.12.2019

\footnotetext{
* Author for correspondence:

${ }^{1}$ Department of Plant Breeding and Genetics, Sardarkrushinagar Dantiwada Agricultural University, Dantiwada (Gujarat) India
} 